\section{British Quaternary studies}

British Quaternary Studies: Recent Advances. Edited by F. W. Shotton. Pp. 298. (Oxford University Press: Oxford, New York and L.ondon. 1977.) $£ 10$.

Al.1. Quaternary scientists stand in Professor F. W. Shotton's debt for his organising and hosting the Tenth Congress of the International Union of Quaternary Research (INQUA) in Birmingham last August. In conjunction with this meeting. Professor Shotton edited British Quaternary Studies: Recent Advances, and copies were distributed to the delegates. Twenty-three authors contributed 20 well-paced hrief reviews on a broad range of Quaternary topics from tills (Shotton 't al.), sea levels (Mitchell). and loess (C'att) to molluscs (Kerney. Norton), beetles (Coope), vegetation (Godwin. Birks), and man (Molleson. Wymer); and from detailed descriptions of local stratigraphic sections (Funnell and West) to the results of computerised glaciological models (Boulton et al.). Most articles summarise work within Britain and describe events over several glacial-interglacial cycles. Mc (ave et al. and Shackleton describe work in the North Sea and the world's oceans.

The context in which this book was published suggests that it is aimed at an international audience and is designed to represent recent British Quaternary studies. Does it meet these goals?

The most successful article for an international audience is Mitchell's discussion of British sea-level changes in the context of oxygen-isotope variations within deep-sea cores. His correlations between the continental record and the isotope curve may be modified in the future. but the local British changes are well described within the framework to which all long-term Quaternary events from all continents must he tied.

Most other articles describe British phenomena in terms of British stratigraphical terms (for example. Hoxnian. Inswichian. Devensian, and so on). This practice requires the non-British reader to seek tables that correlate the British terms to those used on other continents or that link the British events to an ahsolute time-scale or the deep-sea record. No table of this type appears in British Quuternary Studies. Although uncertainty and controversy are always associated with tables of this type. Professor Shotion has constructed such a table in previous publications (for example. G. F. Mitchell et al., Geol.
Soc. Lon. Spec. Rept, 4, 1973) and might have directed the reader to this publication in his introduction. A map locating all sites mentioned in the book would also have helped.

For the timescale of the past 100,000 yr to $2 \mathrm{Myr}$, the British work is well reviewed. Fossil remains and geomorphological features are described in the context of glacial and interglacial periods in Britain. The establishment of this Quaternary sequence of cold and warm periods is one of the most important contributions that Britain has made to Quaternary science. Focussing the reviews primarily on this timescale. however, has led to the exclusion of several types of Quaternary research in which British scientists have pioneered and hold international reputations.

For instance, Molleson and Wymer ably review the long-term archaeological finds in Britain, but no article

\section{Microbial interactions}

Receptors and Recognition. Series B. Vol. 3: Microbial Interactions. Edited by J. L. Reissig. Pp. 436. (Chapman and Hall: London, 1978.) £20.

Two concurrent series are being published on Receptors and Recognition in biological processes: one (Serie: A) is devoted to wide-ranging articles and the other (Series B) deals with detailed consideration of a specific area. This particular volume consists of nine chapters written by experts in their fields, with an overview contributed by the volume editor, Professor J. L. Reissig.

The first chapter, on "Aggregation and Cell Surface Receptors in Cellular Slime Molds", highlights the central role of cyclic AMP in inducing a population of independent amoebae to come together (cell signals) to form slug-like entities. The role of specific cell surface receptors in the final phase of aggregation (called "docking" by the author) is clearly presented.

The next five chapters deal with these two themes, of response to signals and cell surface receptors in bacterial systems. The first of these chapters concerns chemotaxis, and is followed by articles on phage and colicin receptors as constituents of specific transport systems, attachment to animal cells, the binding and entry of DNA in transformation, and redefinition of the mating phenomena in bacteria. The first two chapters of this group are well written and describe interesting areas of work. The chapter on attachment of bacteria to animal cells is somewhat disappointing in that the field is so describes the detailed interactions between man and the environment that have been documented palynologically and archaeologically for Neolithic and more recent times. No review appears of the recently developed palaeomagnetic techniques for studying lake sediments, nor are any of the excellent palaeolimnological and geochemical studies of lake sediments described. The advances in tree-ring research are also missing. These omissions restrict the book to helping mainly those scholars already versed in the British Quaternary who wish to update their knowledge of some but not all aspects of this field.

Thompson Webb

Thompson Webb III is Associate Professor of Geological Sciences at Brown I'niversity, Providence, Rhode Island, and a Visiting Fellow (1977 78) at the Botany school, University of Cambridge, UK.

rapidly moving that it seems rather dated. The last two contributions, on transformation and on mating phenomena, were really quite exciting to read and must be counted as the high spots of the volume.

The topic of mating is extended to the eukaryotic organisms in chapters dealing with mating in the Saccharomyces cerevisiae and Chlamydomonas systems. The concepts of cell to cell interactions in the Ciliata is explored in the next chapter. The volume editor draws together the underlying ideas in the previous chapters in a thoughtprovoking final essay, and supplies a useful Thesaurus of Microbial Interactions.

The major omission in the book is that only single-species systems are examined. It would have been useful to consider how mixed systems behave, hecause in most natural environments mixed communities of microbes play a dominant role. The papers dealing with the bacterial systems all refer briefly to the fact that the growth environment of the organism has important effects on the system under study. However, this parameter is often not considered by many authors and it is clear that much understanding would come if the dynamic nature of bacterial surfaces was fully recognised.

The book is important as it brings together many viewpoints in this rapidly cxpanding field of microbial interactions. It should be read hy all those interested in the topic.

\section{C. Ellwood}

D. C. Ellwood is Head of the Division of Biochemistry at the Microbiological Research Establishment, Porton, and Honorary Professor of Environmental Sciences at the University of Warwick. UK. 